\title{
Implementasi Model IDEAL Problem Solving Berbantuan Media "Beko" Untuk Meningkatkan Prestasi Belajar Materi Keliling dan Luas Lingkaran Siswa Kelas VI Sekolah Dasar
}

\author{
Evi Kurniasih \\ SD Negeri 1 Karangsalam \\ e-mail: veezasmart19@gmail.com
}

\begin{abstract}
This best practice is motivated by the low mathematics achievement of students. This best practice aims to improve mathematics learning achievement on the circumference and area of the circle by implementing the IDEAL Problem Solving model assisted by the "Beko" media for grade VI students of SD Negeri 1 Karangsalam. Best practices are carried out in class VI SD Negeri 1 Karangsalam in semester 1 of the 2019/2020 academic year with a total of 25 students. Collection data techniques using test techniques (written tests) and non-test techniques (observation, journals, and documentation). The data analysis technique used a qualitative descriptive method. The best practice results show that learning mathematics by implementing the IDEAL Problem Solving model assisted by the "Beko" media runs well. Before the action was taken, the preliminary data showed that the class average was 66 with a learning completeness percentage of $36 \%$ (9 students). After the action was taken, the class average increased to 81 with a percentage of $88 \%$ learning completeness (22 students). Student achievement can be categorized as 7 students (28\%) very good category, 10 students (40\%) good category, 5 students (20\%) enough category, and there are 3 students (12\%) in the poor category. Based on the best practice results, the implementation of the IDEAL Problem Solving model assisted by the media "Beko" can improve mathematics learning achievement on the subject matter and the circle area of the VI grade students of SD Negeri 1 Karangsalam.
\end{abstract}

Keywords: Learning Achievement, IDEAL Problem Solving Model, Media "Beko"

Abstrak. Best practise ini dilatarbelakangi karena rendahnya prestasi belajar matematika siswa. Best practise ini bertujuan untuk meningkatkan prestasi belajar matematika materi keliling dan luas lingkaran dengan mengimplementasikan model IDEAL Problem Solving berbantuan media "Beko" pada siswa kelas VI SD Negeri 1 Karangsalam. Best practice dilaksanakan di kelas VI SD Negeri 1 Karangsalam semester 1 Tahun Pelajaran 2019/2020 dengan jumlah 25 siswa. Teknik pengumpulan data dengan menggunakan teknik tes (tes tertulis) dan teknik nontes (observasi, jurnal, dan dokumentasi). Teknik analisis data menggunakan metode deskriptif kualitatif. Hasil best practise yang dilakukan menunjukkan bahwa pembelajaran matematika dengan mengimplementasikan model IDEAL Problem Solving berbantuan media "Beko" berlangsung dengan baik. Sebelum dilakukan tindakan, data awal menunjukkan bahwa rerata kelas 66 dengan persentase ketuntasan belajar 36\% (9 siswa). Setelah dilakukan tindakan, rerata kelas meningkat menjadi 81 dengan persentase ketuntasan belajar 88\% (22 siswa). Prestasi belajar siswa dapat dikategorikan sebanyak 7 siswa ( $28 \%$ ) kategori amat baik, 10 siswa (40\%) kategori baik, 5 siswa (20\%) kategori cukup, dan terdapat 3 siswa (12\%) pada kategori kurang. Berdasarkan hasil best practice, implementasi model IDEAL Problem Solving berbantuan media "Beko" dapat meningkatkan prestasi belajar matematika materi keliling dan luas lingkaran siswa kelas VI SD Negeri 1 Karangsalam. 
Kata kunci: Prestasi Belajar, Model IDEAL Problem Solving, Media "Beko"

\section{PENDAHULUAN}

Pradigma baru pendidikan menekankan pada: 1) proses pembelajaran (learning) daripada mengajar (teaching); 2) diorganisir dalam suatu struktur yang fleksibel, memperlakukan siswa sebagai individu yang memiliki karakteristik khusus dan mandiri; dan 3) merupakan proses yang berkesinambungan dan senantiasa berinteraksi dengan lingkungan (Hadi, 2005:2). Proses aktivitas pembelajaran hendaknya melibatkan siswa dan guru serta interaksi yang terjadi antara keduanya sehingga terciptalah pembelajaran bermakna (meaningful learning). Hal ini mengandung arti bahwa berhasil tidaknya pencapaian tujuan pendidikan tergantung bagaimana proses belajar yang dialami oleh siswa.

Kualitas pendidikan matematika di tanah air masih jauh tertinggal dibandingkan dengan negara lain di dunia, hal ini berdasarkan hasil survei yang mengungkapkan bahwa siswa sekolah kita mempunyai kinerja yang buruk dalam matematika. Hadi (2005:2) menuturkan pada kompetisi internasional, seperti IMO (International Mathematics Olympiad) siswa-siswa kita menunjukkan penampilan yang buruk dan pada studi komparatif internasional TIMSS (Third International Mathematics and Science Study) siswa-siswa kita hanya berada di peringkat 34 dari 38 negara peserta. Realitas di lapangan, mayoritas siswa menganggap matematika sebagai momok dan merupakan mata pelajaran yang sulit.

Berdasarkan observasi awal yang telah dilakukan, diketahui bahwa penguasaan materi pada muatan pelajaran matematika masih jauh dari harapan. Hal tersebut terlihat dari hasil tes prestasi belajar pada penilaian harian materi lingkaran dari 25 siswa, sebagian besar siswa belum mencapai Kriteria Ketuntasan Minimal (KKM) 64. Hanya 9 siswa (36\%) yang mampu memperoleh nilai di atas KKM. Sisanya, 16 siswa (64\%) masih di bawah KKM dengan rerata kelas 66. Hal ini jauh dari harapan guru yang menargetkan pencapaian ketuntasan belajar hingga $75 \%$. Berdasarkan data tersebut sehingga dimungkinkan matematika bagi siswa kelas VI SD Negeri 1 Karangsalam merupakan muatan pelajaran yang sulit.

Permasalahan lain yang ditemui diantaranya motivasi siswa rendah sehingga penguasaan materi matematika masih kurang dan banyak muncul aktivitas yang tidak relevan. Selama ini, pembelajaran matematika masih konvensional yaitu didominasi ceramah, siswa hanya mendengarkan penjelasan guru kemudian menyelesaikan latihan soal dan pada kenyataannya siswa belum mampu menyelesaikan soal dengan baik. Kurang adanya upaya guru untuk mengaitkan materi pembelajaran dengan kehidupan sehari-hari (kontekstual atau real) siswa maupun pemanfaatan bendabenda konkret di sekitar siswa sehingga pembelajaran yang bermakna bagi siswa kurang tercipta. Selain itu, guru juga kurang mengembangkan kegiatan pembelajaran inovatif untuk memfasilitasi kebutuhan siswa yang berbeda dengan pemanfaatan model pembelajaran ataupun metode pembelajaran yang bervariasi. 
Sesuai dengan observasi awal, terkait prestasi belajar materi lingkaran yang rendah maka dalam memahami materi keliling dan luas lingkaan diperlukan suatu proses pada diri siswa untuk mencoba dan melakukan analisis pada suatu objek. Oleh karena itu diperlukan suatu usaha yang menjadikan pembelajaran berpusat pada siswa dengan kegiatan pembelajaran yang mengaktifkan siswa untuk mengkonstruksi materi pelajaran dengan memanfaatkan bendabenda konkret di sekitar siswa sehingga akan menunjukkan suatu perubahan hasil belajar yang optimal.

Pemecahan masalah merupakan komponen penting dari kurikulum matematika dan di dalamnya terdapat inti dari aktivitas matematika, sehingga kemampuan pemecahan masalah di kalangan siswa perlu mendapat perhatian dalam pembelajaran. Pemecahan masalah juga merupakan ciri dari pembelajaran yang mengedepankan keterampilan berpikir tingkat tinggi. Menurut Bruner (dalam Nayazik dan Sukestiyarno, 2012:2) kunci keterlibatan siswa dalam penyelesaian masalah adalah pengembangan terhadap perencanaan pembelajaran yang fokus terhadap masalah-masalah yang terjadi saat ini.

Salah satu model pembelajaran yang dapat menjembatani pembelajaran pemecahan masalah adalah IDEAL Problem Solving. Model pembelajaran ini pertama kali dikenalkan oleh Bransford dan Stein pada tahun 1993. Menurut Gick dan Holyoak (dalam Wena, 2011:87) model IDEAL Problem Solving mengakomodasi tiga aktivitas kognitif dalam pemecahan masalah, yaitu penyajian masalah, pencarian pemecahan masalah, dan penerapan solusi serta mengevaluasi hasilnya. Wena (2011:88-89) menuturkan langkah-langkah dalam pembelajaran model IDEAL Problem Solving sesuai dengan singkatan IDEAL sebagai berikut.

1. I-Identify the problem (Mengidentifikasi masalah).

Identifikasi masalah merupakan tahap awal dari model pembelajaran ini. Dalam tahap ini guru membimbing siswa untuk memahami aspek-aspek permasalahan, seperti membimbing siswa untuk mengembangkan atau menganalisis permasalahan, mengajukan pertanyaan, mengkaji hubungan antardata, memetakan masalah, dan mengembangkan hipotesishipotesis.

2. D-Define the goal (Menentukan tujuan)

Dalam tahap ini, kegiatan guru membimbing siswa untuk melihat hal/data/variabel yang sudah diketahui dan belum diketahui, mencari berbagai informasi, menyaring berbagai informasi yang ada dan akhirnya merumuskan tujuan dari suatu permasalahan.

3. E-Explore solution (Mencari solusi)

Dalam tahap ini, kegiatan guru membimbing siswa mencari berbagai alternatif pemecahan masalah, melakukan brainstorming, melihat alternatif pemecahan masalah dari berbagai sudut pandang dan akhirnya memilih satu alternatif pemecahan masalah yang paling tepat.

4. A-Act on strategy (Melaksanakan strategi) 
Melakukan langkah pemecahan masalah sesuai dengan alternatif yang telah dipilih. Dalam tahap ini siswa dibimbing secara tahap demi tahap dalam melakukan pemecahan masalah sesuai strategi yang dipilih.

5. L-Look back and evaluate the effect (Mengkaji kembali dan mengevaluasi pengaruh)

Dalam tahap ini, guru membimbing siswa melihat/mengoreksi kembali cara-cara pemecahan masalah yang telah dilakukan, apakah sudah benar, sudah sempurna, atau sudah lengkap. Di samping itu, siswa juga dibimbing untuk melihat pengaruh strategi yang digunakan dalam pemecahan masalah.

Model IDEAL Problem Solving memiliki kelemahan yaitu membutuhkan waktu yang tidak sedikit dalam pembelajarannya sehingga guru harus pandai memanagemen waktu sehingga tujuan pembelajaran dapat tercapai. Sedangkan kelebihan model IDEAL Problem Solving yaitu model pembelajaran yang dapat menggali kreativitas siswa dalam menyelesaikan masalah sehingga siswa dapat memiliki keterampilan dalam memecahkan masalah yang dihadapi. Selain itu, tahapan atau sintaks model IDEAL Problem Solving juga dapat melatih siswa untuk mengemukakan ide yang ada di pikirannya dan berpikir kritis untuk memecahkan masalah.

Diperkuat oleh Bransford dan Stein (dalam Susiana, 2010:75) bahwa kelebihan IDEAL Problem Solving sebagai model penyelesaian masalah yang mampu meningkatkan kemampuan berpikir dan meningkatkan keterampilan dalam proses penyelesaian masalah. Permasalahan yang disajikan merupakan permasalahan kontekstual yang ada di sekeliling siswa. Guru dapat memanfaatkan benda-benda konkret berbentuk lingkaran dalam pembelajaran matematika agar matematika tidak lagi abstrak tetapi sebuah proses belajar mengajar yang bermakna bagi siswa. Menurut Siswoyo dkk (2007:109) penggunaan konteks nyata atau dunia nyata dalam pembelajaran dimaksudkan agar sejalan dengan tahap perkembangan kognitif siswa menurut Jean Piaget yaitu anak usia 7-11 tahun berada pada fase operasional konkret. Mereka lebih suka belajar dengan bekerja dan akan memaksimalkan keterlibatan siswa secara aktif dalam proses pembelajaran sehingga siswa dapat mengaplikasikan kembali ke dalam kehidupan nyatanya.

Hal tersebut senada dengan pendapat Bruner tentang tahap perkembangan kognitif siswa sebagai proses belajar terbagi dalam tiga tahapan, yaitu: 1) Tahap enaktif (menggunakan benda-benda konkret atau mengalami peristiwa di dunia sekitarnya); 2) Tahap ikonik (siswa menyajikan pengetahuan dalam bentuk bayangan mental atau menyajikan gambaran dari objek yang dimanipulasinya); dan 3) Tahap simbolik (siswa dapat mengutarakan bayangan mental tersebut dalam bentuk simbol dan bahasa) (Karso, 2008:1.12).

$$
\text { Pemanfaatan media dalam }
$$
pembelajaran perlu dilakukan terlebih apabila guru mampu menghadirkan benda konkret dalam pembelajaran. Secara umum media merupakan kata jamak dari "medium" yang berarti perantara atau pengantar. Menurut Martin \& Briggs (dalam Wena, 2011:9) media pembelajaran adalah semua 
sumber yang diperlukan untuk melakukan komunikasi dengan siswa. Lebih lanjut, Muhsetyo (2008:2.3) mengartikan media pembelajaran sebagai alat bantu pembelajaran yang secara sengaja dan terencana disiapkan atau disediakan guru untuk mempresentasikan dan/atau menjelaskan bahan pelajaran sehingga siswa terlibat langsung dalam pembelajaran.

Hal tersebut diperkuat oleh pendapat Ibrahim dan Syaodih (2003:118) yang menuturkan untuk mencapai hasil yang optimal dari proses belajar mengajar salah satu yang disarankan yaitu dengan digunakannya media yang bersifat langsung, bersifat nyata atau realita. Benda konkret berperan memberikan rangsangan bagi siswa dalam mempelajari banyak hal terutama yang menyangkut keterampilan tertentu.

Benda menurut Kamus Besar Bahasa Indonesia mengandung pengertian segala yang ada dalam alam yang berwujud atau berjasad (bukan roh). Konkret sendiri berarti nyata; benar-benar ada (berwujud, dapat dilihat, diraba, dan sebagainya). Dapat diidentifikasi melalui panca indera manusia, benda yang sebenarnya sebagai alat belajar.

Jadi yang dimaksud media benda konkret yang kemudian dalam best practise ini disingkat menjadi "Beko" adalah media pembelajaran yang berasal dari benda-benda atau barang nyata atau konkret yang ada di sekitar siswa yang dapat dimanfaatkan sebagai stimulus dalam pembelajaran sehingga membantu siswa untuk memahami materi pembelajaran.

Benda-benda konkret yang digunakan dalam best practise ini berbentuk benda nyata yang mengandung unsur lingkaran yang telah dikenal siswa, seperti: jam dinding, toples, piring, botol minum, spidol, lakban, ember, hulahop, uang logam, roti berbentuk lingkaran, dan sebagainya. Penggunaan media pembelajaran benda konkret tentunya memiliki kelebihan dan kekurangan. Adapun kelebihan media benda konkret yaitu: media dapat menerjemahkan ide/ konsep yang abstrak menjadi nyata, mudah didapat, dan mudah digunakan. Sedangkan kelemahan dari media benda konkret adalah tidak tahan lama dan terbatas penggunaannya dalam materi pelajaran (Winataputra, 2005:5.9).

Berdasarkan pemaparan di atas, secara garis besar pemanfaatan media ditujukan untuk meningkatkan kualitas pembelajaran. Khususnya pada best practise ini, penulis memanfaatkan bendabenda konkret "Beko" dalam pembelajaran matematika materi keliling dan luas lingkaran yang ditujukan untuk membantu siswa dalam memahami konsep keliling dan luas lingkaran serta memberikan pengalaman belajar sehingga lebih merangsang minat siswa untuk belajar yang pada akhirnya mampu meningkatkan prestasi belajar matematika siswa.

Belajar dapat diartikan perubahan tingkah laku atau penampilan, dengan serangkaian kegiatan misalnya dengan membaca, mengamati, mendengarkan, meniru, dan lain sebagainya (Sardiman, 2014:20). Hasil dari belajar dalam konteks pendidikan sering disebut sebagai prestasi belajar. Jadi prestasi belajar tidak dapat dipisahkan dengan kegiatan belajar, karena kegiatan belajar merupakan proses, sedangkan prestasi adalah hasil dari pembelajaran tersebut. Prestasi belajar menurut Alya (2009:568) adalah hasil yang telah dicapai (dari yang telah dilakukan, dikerjakan). Prestasi belajar merupakan suatu bukti keberhasilan belajar atau kemampuan seseorang siswa 
dalam melakukan kegiatan belajarnya sesuai dengan bobot yang dicapai. Proses belajar akan menghasilkan prestasi belajar yakni perubahan perilaku kognitif, afektif, dan psikomotor yang terjadi dalam diri siswa.

Berdasarkan keseluruhan pendapat di atas dapat disimpulkan bahwa prestasi belajar matematika merupakan gambaran keberhasilan yang telah dicapai siswa setelah melalui kegiatan atau pengalaman belajar matematika dalam kurun waktu tertentu sesuai dengan tujuan pembelajaran yang ditetapkan. Indikator prestasi belajar matematika yang dimaksud dalam best practise ini diperoleh melalui tes akhir (tes tertulis) yang dapat dilihat dari skor yang dicapai siswa.

Lingkaran merupakan salah satu jenis bangun datar. Lingkaran banyak terdapat dalam kehidupan sehari-hari. Lingkaran adalah titik-titik pada bidang datar yang berjarak sama terhadap suatu titik tertentu (Gunanto dan Adhalia, 2016:64). Titik itu disebut dengan pusat lingkaran dan jarak yang sama itu dinamakan jari-jari lingkaran. Garis yang menghubungkan sisi lingkaran melalui titik pusat dinamakan diameter lingkaran. Pada pokok bahasan mengenai lingkaran di kelas VI kurikulum 2013 salah satunya Kompetensi Dasar 3.5 Menjelaskan taksiran keliling dan luas lingkaran dan 4.5 Menaksir keliling dan luas lingkaran serta menggunakannya untuk menyelesaikan masalah. Berdasarkan observasi awal, penguasaan materi lingkaran oleh siswa kelas VI masih rendah sehingga pada best practice ini, penulis melaksanakan pembelajaran matematika terutama pada materi keliling dan luas lingkaran. Keliling lingkaran adalah panjang busur lingkaran yang ditentukan oleh jari-jari lingkarannya. Andaikan suatu benda mengelilingi lingkaran, maka panjang lintasannya sama dengan perkalian antara panjang jari-jari dan besar sudut saat benda mengelilingi lingkaran. Luas lingkaran adalah luas daerah yang terletak di dalam lingkaran.

Rumusan masalah dalam best practice ini adalah bagaimana implementasi model IDEAL Problem Solving berbantuan media "Beko" dapat meningkatkan prestasi belajar materi keliling dan luas lingkaran siswa kelas VI SD Negeri 1 Karangsalam? Tujuan dilaksanakannya best practice ini adalah meningkatkan prestasi belajar materi keliling dan luas lingkaran pada muatan pelajaran matematika siswa kelas VI di SD Negeri 1 Karangsalam dan secara khusus, best practice ini bertujuan untuk mendeskripsikan implementasi proses pembelajaran model IDEAL Problem Solving berbantuan media "Beko" atau benda-benda konkret yang ada di sekitar siswa yang digunakan untuk meningkatkan prestasi belajar materi keliling dan luas lingkaran pada muatan pelajaran matematika untuk siswa kelas VI SD Negeri 1 Karangsalam. Manfaat yang diharapkan dari best practice ini adalah meningkatkan prestasi belajar matematika dan kreativitas siswa dalam memanfaatkan sumber belajar bendabenda konkret yang ada di lingkungan, menambah wawasan pengetahuan kreativitas guru, dan pengalaman tentang model dan media pembelajaran untuk meningkatkan profesionalitas dalam tugas, pokok, dan fungsi guru.

Berdasarkan hasil observasi terhadap kompleksitas permasalahan yang ditemui penulis maka perlu dilakukan sebuah usaha perbaikan atau tindakan secara tepat dan akurat berupa best practice untuk meningkatkan kualitas pembelajaran matematika. Sebagai 
alternatif untuk meningkatkan prestasi belajar matematika materi keliling dan luas lingkaran pada siswa kelas VI SD Negeri 1 Karangsalam yaitu dengan implementasi model pembelajaran IDEAL Problem Solving berbantuan media "Beko" (Benda konkret).

\section{METODE}

Best practice ini dilakukan di SD Negeri 1 Karangsalam Kecamatan Susukan Kabupaten Banjarnegara pada muatan pelajaran matematika semester 1 tahun pelajaran 2019/2020 selama dua kali pertemuan. Pertemuan 1 pada hari Rabu, 23 Oktober 2019 dan pertemuan 2 pada hari Sabtu, 26 Oktober 2019. Pelaksanaan kegiatan pembelajaran di minggu keempat Oktober 2019. Diawali dengan penyusunan perencanaan pada bulan Agustus 2019. Penyusunan instrumen penelitian pada bulan September 2019. Penyusunan laporan dimulai awal bulan November 2019 dilanjutkan dengan seminar best practice pada minggu ketiga November 2019.

Subjek yang digunakan adalah siswa kelas VI dengan jumlah 25 siswa, terdiri dari 12 siswa laki-laki dan 13 siswa perempuan. Teknik pengumpulan data dengan menggunakan teknik tes (berupa tes tertulis untuk mengetahui prestasi belajar matematika materi keliling dan luas lingkaran) dan teknik nontes (berupa observasi, jurnal, dan dokumentasi). Teknik analisis data menggunakan metode deskriptif kualitatif.

\section{HASIL}

Sebelum dilakukan best practice kondisi pembelajaran matematika masih konvensional dan monoton, kurangnya inovasi pembelajaran dalam hal model pembelajaran, media pembelajaran maupun alat peraga serta kurangnya guru menghubungkan pembelajaran dengan kehidupan nyata karena siswa hanya mengerjakan latihan soal tanpa mengetahui kebermaknaan pembelajaran. Kondisi proses pembelajaran ini berakibat prestasi belajar siswa rendah. Hal ini ditunjukkan hasil telaah dokumentasi berdasarkan nilai prestasi belajar materi pokok lingkaran dari 25 siswa. Secara lengkap prestasi belajar siswa pada kondisi awal disajikan dalam tabel berikut.

Tabel 1. Data Awal Prestasi Belajar sebelum Implementasi Model IDEAL Problem Solving Berbantuan Media

\begin{tabular}{llll}
\multicolumn{4}{c}{ "Beko" } \\
\hline \multirow{2}{*}{$\begin{array}{l}\text { Rentang } \\
\text { Nilai }\end{array}$} & \multicolumn{3}{c}{ Data Awal } \\
\cline { 2 - 4 } & Frekuensi & Prosentase & \\
\cline { 2 - 4 } $88-100$ & 2 & $8 \%$ & Amat Baik \\
\hline $76-87$ & 5 & $20 \%$ & Baik \\
\hline $64-76$ & 2 & $8 \%$ & Kurang \\
\hline$<63$ & 16 & $64 \%$ & \\
\hline Rata- Rata & \multicolumn{2}{c}{$\mathbf{6 6}$} \\
\hline $\begin{array}{l}\text { Ketuntas- } \\
\text { an Belajar }\end{array}$ & $\mathbf{3 6 \%}$ \\
\hline $\begin{array}{l}\text { Tidak } \\
\text { Tuntas }\end{array}$ & & $\mathbf{6 4 \%}$ \\
\hline
\end{tabular}

Tabel 1 menunjukkan hanya 2 siswa $(8 \%)$ yang mendapat nilai kategori amat baik, terdapat 5 siswa (20\%) yang mendapat nilai kategori baik, 2 siswa (8\%) yang mendapat nilai kategori cukup, dan sebanyak 16 siswa (64\%) yang mendapat nilai kategori kurang. Sebanyak 9 siswa (36\%) mencapai ketuntasan dalam materi pokok lingkaran dan 16 siswa (64\%) tidak tuntas belajar dengan rata-rata kelas sebesar 66. Secara umum prestasi belajar matematika dalam proses pembelajaran matematika di SD Negeri 1 Karangsalam kelas VI secara persentase ketuntasan belajar masih belum memuaskan.

Data tentang prestasi belajar siswa materi keliling dan luas lingkaran 
diperoleh setelah melakukan pembelajaran yang mengimplementasikan Model IDEAL Problem Solving berbantuan media "Beko" diambil dengan menggunakan instrumen data berupa tes akhir yang disajikan dalam tabel berikut.

Tabel 2. Data Best Practise Prestasi Belajar setelah Implementasi Model IDEAL Problem Solving Berbantuan

\begin{tabular}{|c|c|c|c|}
\hline \multicolumn{4}{|c|}{ Media "Beko" } \\
\hline \multirow{2}{*}{$\begin{array}{l}\text { Rentang } \\
\text { Nilai }\end{array}$} & \multicolumn{2}{|c|}{ Prestasi Belajar } & \multirow{2}{*}{ Kriteria } \\
\hline & Frekuensi & Prosentase & \\
\hline $88-100$ & 7 & $28 \%$ & Amat Baik \\
\hline $76-87$ & 10 & $40 \%$ & Baik \\
\hline $64-76$ & 5 & $20 \%$ & Cukup \\
\hline$<63$ & 3 & $12 \%$ & Kurang \\
\hline Rata-Rata & \multicolumn{3}{|c|}{81} \\
\hline $\begin{array}{l}\text { Ketuntas- } \\
\text { an Belajar }\end{array}$ & \multicolumn{3}{|c|}{$88 \%$} \\
\hline $\begin{array}{l}\text { Tidak } \\
\text { Tuntas }\end{array}$ & \multicolumn{3}{|c|}{$12 \%$} \\
\hline
\end{tabular}

Tabel 2 menunjukkan prestasi belajar matematika materi keliling dan luas lingkaran sebanyak 7 siswa (28\%) kategori amat baik, sebanyak 10 siswa (40\%) memperoleh prestasi belajar matematika kategori baik, terdapat 5 siswa $(20 \%)$ berada pada kategori prestasi belajar matematika cukup, dan hanya 3 siswa $(12 \%)$ yang nilai atau prestasi belajar matematika dibawah 64 atau kategori kurang. Sehingga dapat diartikan terdapat 22 siswa (88\%) telah memenuhi KKM atau ketuntasan belajar dengan ratarata kelas 81 , sedangkan yang tidak tuntas sebanyak 3 siswa (12\%).

Hasil best practice implementasi model IDEAL Problem Solving berbantuan media "Beko" untuk meningkatkan prestasi belajar materi keliling dan luas lingkaran apabila disajikan dalam bentuk diagram batang sebagai berikut.

\section{Gambar 1. Perbandingan Prestasi Belajar Siswa Pada Data Awal dan Data Best Practise}

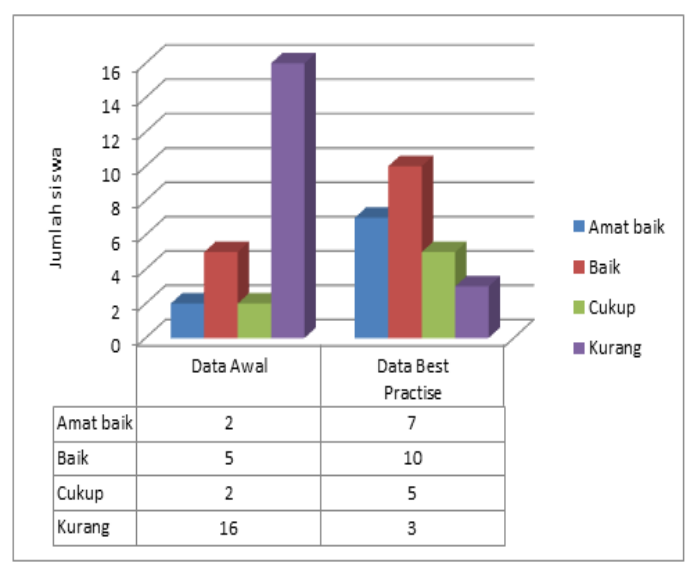

Gambar 1 di atas menunjukkan perbandingan data awal dan data setelah dilakukan best practice berupa prestasi belajar siswa. Pada kategori amat baik, terjadi peningkatan jumlah siswa sebanyak 5 siswa, dari yang awalnya 2 siswa meningkat menjadi 7 siswa. Kategori baik juga mengalami peningkatan jumlah siswa sebanyak 5 siswa, dari yang awalnya 5 siswa menjadi 10 siswa. Kategori cukup, terdapat kenaikan jumlah siswa sebanyak 3 siswa, yang awalnya hanya 2 siswa, setelah best practice meningkat menjadi 5 siswa. Sedangkan prestasi belajar pada kategori kurang, jumlah siswa menurun sebanyak 13 siswa, dari sebelum best practise 16 siswa yang memperoleh prestasi belajar kategori kurang menjadi hanya 3 siswa. Hal ini menunjukkan bahwa prestasi belajar siswa mengalami kenaikan yang cukup signifikan.

Sesuai dengan pemaparan di atas, maka penulis menjelaskan lebih lanjut mengenai pelaksanaan pembelajaran yang mengimplementasikan model IDEAL Problem Solving berbantuan media "Beko" dapat meningkatkan prestasi belajar matematika siswa kelas VI SD Negeri 1 Karangsalam. Hal itu terbukti dari hasil 
analisis data yang telah diperoleh selama implementasi yang menunjukkan peningkatan prestasi belajar keliling dan luas lingkaran yang memuaskan dan divisualkan pada grafik berikut.

\section{Gambar 2. Implementasi Model IDEAL Problem Solving Berbantuan Media "Beko" untuk Meningkatkan Prestasi Belajar Siswa}

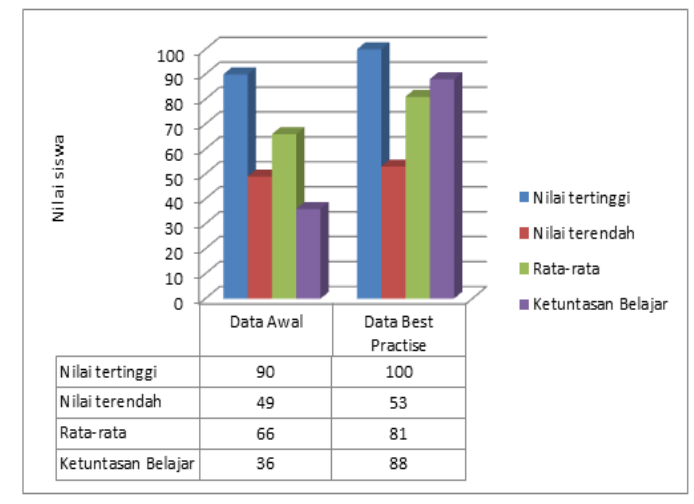

Berdasarkan gambar 2 di atas, diperoleh keterangan sebagai berikut.

1. Nilai tertinggi pada data awal adalah 90, pada kegiatan best practise mengalami kenaikan menjadi 100 .

2. Nilai terendah pada data awal adalah 49, pada kegiatan best practise mengalami kenaikan menjadi 53.

3. Nilai rata-rata kelas pada data awal adalah 66, pada kegiatan best practise juga mengalami kenaikan menjadi 81 .

4. Ketuntasan belajar siswa pada data awal hanya $36 \%$ sedangkan pada kegiatan best practise naik menjadi $88 \%$.

Berdasarkan hasil perbandingan antara data awal dan data best practise, dapat disimpulkan bahwa implementasi model IDEAL Problem Solving berbantuan media "Beko" dapat meningkatkan prestasi belajar siswa kelas VI SD Negeri 1 Karangsalam ditandai dengan rata-rata kelas yang meningkat dan ketuntasan belajar secara klasikal yang melebihi $75 \%$. Hal tersebut sejalan dengan pendapat Djamarah dan Zain (2006:108) apabila 75\% dari jumlah siswa yang mengikuti proses belajar mengajar mencapai taraf keberhasilan minimal, optimal, atau bahkan maksimal, maka proses belajar mengajar berikutnya dapat membahas pokok bahasan yang baru. Diperkuat oleh Sudjati (2009:1) bahwa target ketuntasan secara nasional diharapkan mencapai minimal nilai $75 \%$.

Berdasarkan hasil observasi ketika implementasi model IDEAL Problem Solving berbantuan media "Beko" dalam pembelajaran matematika, tercipta pengelompokan siswa bersifat heterogen. Hal tersebut memberikan dampak positif yaitu terjadinya transfer ilmu pengetahuan, siswa yang mampu membantu siswa yang membutuhkan. Model IDEAL Problem Solving menuntut siswa aktif dan kreatif dalam memecahkan masalah karena siswa diberi kesempatan untuk bereksplorasi dengan mengkombinasikan pengetahuan yang dimilikinya.

Melalui model IDEAL Problem Solving berbantuan media "Beko" akan memberikan pemahaman kepada siswa terkait dengan konsep ilmu lain yang terkandung dalam konsep matematika yaitu tentang konsep keliling lingkaran pada pertemuan 1 dan konsep luas lingkaran dalam pertemuan 2. Tentu saja hal tersebut dapat mengembangkan penalaran sekaligus melatih kemandirian siswa dalam pembelajaran sehingga pembelajaran bermakna bagi siswa. Guru sudah bertindak sebagai pembimbing, fasilitator, dan motivator dalam pembelajaran.

Pembelajaran dirasakan berbeda dengan pembelajaran sebelumnya karena pembelajaran melalui model IDEAL Problem Solving berbantuan media "Beko" dimulai dengan konteks nyata yang dijadikan starting point pembelajaran dan 
masalah realistik yang diberikan mengarah kepada tujuan pembelajaran. Seperti pada pertemuan 1 dengan tujuan pembelajaran menentukan rumus keliling lingkaran, kegiatan pembelajaran dimulai dengan tahap 1 model IDEAL Problem Solving yaitu mengidentifikasi masalah. Siswa melakukan unjuk kerja dengan menggelindingkan uang logam sebanyak satu putaran. Media "Beko" yang digunakan adalah uang logam sehingga siswa menemukan masalah terkait keliling lingkaran. Masalah nyata juga digunakan saat pertemuan 2 dengan tujuan menentukan rumus luas lingkaran. Media "Beko" yang digunakan adalah roti berbentuk lingkaran. Roti yang dipotong menjadi beberapa juring kemudian melalui juring-juring tersebut, siswa menemukan masalah terkait luas lingkaran.

Tahap 2 model IDEAL Problem Solving adalah menentukan tujuan. Berdasarkan kegiatan yang sudah dilakukan pada tahap sebelumnya maka siswa menentukan tujuan dari kegiatan pada pertemuan 1 yaitu konsep keliling lingkaran maupun pada pertemuan 2 yaitu konsep luas lingkaran.

Tahap 3 dalam model IDEAL Problem Solving adalah mencari solusi. Pada kegiatan ini, siswa memanfaatkan media "Beko" atau benda-benda konkret berbentuk lingkaran di sekeliling siswa. Pada pertemuan 1, siswa mengukur keliling dan diameter lingkaran dari benda-benda konkret yang dibawanya dari rumah, seperti spidol, botol minuman, gayung, jam dinding, botol lem, hulahop, toples, dan lain-lain dengan menggunakan pita. Selain itu, siswa sangat antusias mengukur keliling dan diameter lingkaran dari benda-benda berbentuk lingkaran di luar kelas. Pada pertemuan 2, siswa memanfaatkan benda- benda konkret berbentuk lingkaran untuk ditentukan luas lingkarannya, dengan cara menjiplak benda tersebut kemudian membaginya menjadi 8 juring atau 12 juring. Pada tahap ini, kreativitas dan kemampuan pemecahan masalah siswa digali. Melalui proses berpikir dan pengumpulan informasi, siswa dapat menemukan rumus keliling lingkaran yaitu $\mathrm{K}=2 \pi r$ atau $\mathrm{K}=\pi d$ dan rumus luas lingkaran yaitu $\mathrm{L}=\pi r^{2}$.

Gambar 3 di bawah ini menunjukkan suasana diskusi kelompok ketika pembelajaran berlangsung. Terlihat jelas bahwa siswa sangat antusias menemukan solusi dari permasalahan yang disajikan.

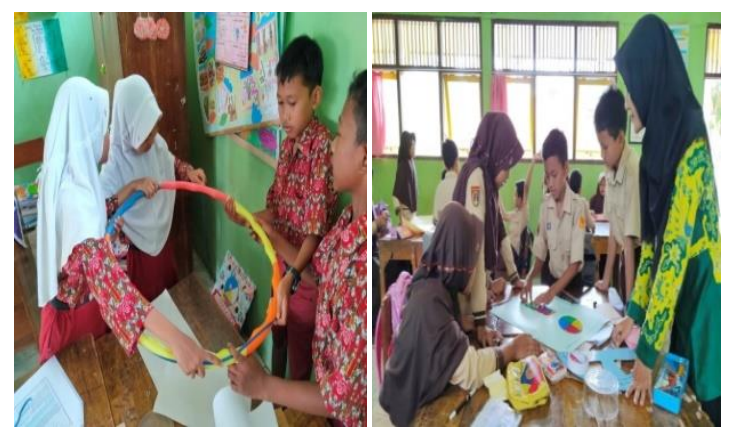

Gambar 3. Suasana Diskusi Kelompok

Melaksanakan strategi merupakan tahapan ke-4 dalam model IDEAL Problem Solving. Pada kegiatan ini, siswa dihadapkan pada situasi baru atau permasalahan baru berupa penerapan dari rumus keliling lingkaran pada pertemuan 1 dan rumus luas lingkaran pada pertemuan 2 yang sudah siswa temukan. Dalam pemecahan masalah, siswa memerlukan kemampuan mengorganisasikan strategi. Berikut adalah contoh strategi yang ditempuh siswa dalam menyelesaikan masalah pada soal LKS 1 dengan kelompoknya. 

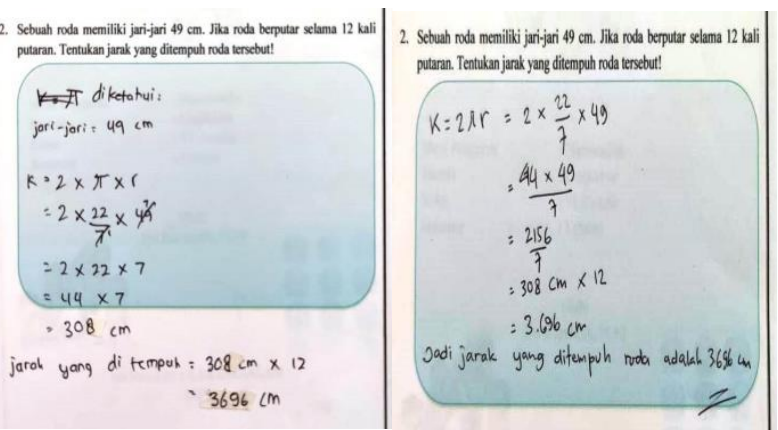

Gambar 4. Strategi Pemecahan Masalah Siswa Dalam Situasi Baru Pada Penerapan Taksiran Keliling Lingkaran

Berdasarkan gambar 4 di atas, terlihat contoh strategi yang ditempuh oleh dua kelompok, strategi pada kelompok 1 (gambar sebelah kiri) untuk menentukan jarak yang ditempuh roda, siswa mencari keliling roda terlebih dahulu kemudian strategi selanjutnya siswa mengalikan hasil penghitungan keliling roda dengan jumlah putaran. Sedangkan pada kelompok 5 (gambar sebelah kanan) untuk menentukan jarak yang ditempuh roda, siswa menghitung keliling roda sekaligus mengalikan dengan jumlah putaran roda.

Tahap terakhir dalam model IDEAL Problem Solving adalah mengkaji kembali dan mengevaluasi pengaruh. Siswa secara bergantian mempresentasikan hasil kerja kelompoknya di depan kelas, sedangkan kelompok lain memberikan tanggapan atas hasil presentasi kelompok yang tampil. Guru sebagai fasilitator dengan memberikan konfirmasi dalam diskusi kelas dan memberikan penegasan terhadap pemecahan masalah yang dilakukan siswa kemudian mengevaluasi kecocokan antara tujuan pembelajaran yang ingin dicapai dengan hasil yang didapat pada pertemuan tersebut.

Berdasarkan pembahasan mengenai kelima tahapan model IDEAL Problem
Solving berbantuan media "Beko" di atas tampak bahwa model ini dapat menggali kreativitas siswa dalam menyelesaikan masalah sehingga siswa dapat memiliki keterampilan pemecahan masalah yang dihadapi. Hal tersebut diperkuat oleh Indriyani dan Masriyah (2016:101-102) yaitu tahap-tahap model pembelajaran IDEAL Problem Solving dapat melatih siswa untuk mengemukakan ide yang dimilikinya, berpikir kritis untuk memecahkan masalah, berpikir sistematis dan logis sesuai data yang tersedia, dan melatih siswa untuk saling berinteraksi dengan teman maupun guru. Selain itu, menurut Suherman menyatakan belajar matematika tidak hanya sekedar learning to know melainkan harus ditingkatkan meliputi learning to do, learning to be hingga pada learning to live together. Artinya matematika harus mampu menjadi sarana bagi siswa untuk meningkatkan daya nalar siswa dan dapat meningkatkan kemampuan untuk mengaplikasikan matematika untuk menghadapi tantangan hidup dalam memecahkan masalah.

Hasil jurnal siswa menunjukkan bahwa siswa merasa senang dan tertarik dengan implementasi pembelajaran model IDEAL Problem Solving berbantuan media "Beko" yang telah dilaksanakan. Siswa senang karena pembelajaran tidak hanya di dalam kelas namun juga dilaksanakan di luar kelas. Suasana pembelajaran yang menyenangkan sebagai salah satu solusi untuk menumbuhkan minat dan motivasi belajar siswa sehingga dengan adanya minat dan motivasi yang tinggi diharapkan dapat berimbas pada peningkatan prestasi belajar matematika. Siswa menyukai bekerja sama dalam kelompok, karena siswa dapat belajar menghargai dan menghormati satu sama lain. Menurut 
siswa, melalui penggunaan benda-benda konkret dapat mempermudah pembelajaran sehingga siswa menyukainya. Siswa merasa asyik ketika menentukan keliling dan diameter menggunakan pita pada benda-benda yang mereka bawa dari rumah. Selain itu siswa juga menyukai ketika memotong roti menjadi beberapa juring. Salah satu bonusnya adalah roti tersebut boleh dimakan di akhir pembelajaran. Melalui penerapan media "Beko" menjadikan pembelajaran lebih kontekstual karena siswa mendapat pengalaman belajar melalui pengalaman langsung untuk menemukan sebuah konsep pengetahuan sehingga lebih termemori di pikiran siswa. Menurut Sanjaya (2012:62) pengalaman langsung adalah pengalaman yang diperoleh melalui aktivitas sendiri pada situasi yang sebenarnya. Kesulitan yang dialami siswa adalah ketika mengerjakan soal yang membutuhkan pemahaman soal dan kemampuan menghitung serta kurang percaya diri ketika mengungkapkan pendapatnya. Kesulitan tersebut diatasi oleh guru dengan adanya peran guru sebagai motivator dan fasilitator.

\section{SIMPULAN}

Berdasarkan pemaparan di atas, maka dapat diambil kesimpulan bahwa pembelajaran melalui implementasi model IDEAL Problem Solving berbantuan media "Beko" dapat meningkatkan prestasi belajar matematika materi keliling dan luas lingkaran siswa kelas VI SD Negeri 1 Karangsalam semester 1 tahun pelajaran 2019/2020. Peningkatan ini terlihat dari hasil peningkatan nilai rerata kelas dan persentase ketuntasan belajar siswa. Data awal diperoleh rerata kelas 66 dengan persentase ketuntasan belajar 36\% atau 9 siswa. Setelah dilakukan implementasi model IDEAL Problem Solving berbantuan media "Beko" rerata kelas meningkat menjadi 81 dengan persentase ketuntasan belajar $88 \%$ atau 22 siswa. Prestasi belajar siswa dapat dikategorikan sebanyak 7 siswa (28\%) kategori amat baik, 10 siswa (40\%) kategori baik, 5 siswa (20\%) kategori cukup, dan terdapat 3 siswa (12\%) pada kategori kurang. Selain itu melalui implementasi model IDEAL Problem Solving berbantuan media "Beko" pada materi keliling dan luas lingkaran menjadikan terciptanya pembelajaran matematika yang bersifat student centered dan lebih menyenangkan.

\section{DAFTAR PUSTAKA}

Alya, Q. (2009). Kamus Bahasa Indonesia untuk Pendidikan Dasar. Jakarta: PT INDAHJAYA Adipratama.

Depdiknas. (2002). Kamus Besar Bahasa Indonesia. Jakarta: Balai Pustaka.

Djamarah, S. B., dan Zain, A. (2006). Strategi Belajar Mengajar. Jakarta: PT Rineka Cipta.

Gunanto dan Adhalia, D. (2016). ESPS "Erlangga Straight Point Series" Matematika untuk SD/MI Kelas VI. Jakarta: Erlangga.

Hadi, S. (2005). Pendidikan Matematika Realistik dan Implementasinya. Banjarmasin: Tulip.

Ibrahim, R dan Syaodih, N. (2003). Perencanaan Pengajaran. Jakarta:Rineka Cipta.

Indriyani, R.W dan Masriyah. (2016). Penerapan Model Pembelajaran IDEAL Problem Solving dalam Menyelesaikan Masalah Matematika 
pada Materi Keliling dan Luas Persegi Panjang dan Persegi bagi Siswa Kelas VII SMP. Jurnal Mathedunesa: Jurnal ilmiah Pendidikan Matematika. Vol. 2 No. 5 (2016). pp. 100-108.

(Online). (https://jurnalmahasiswa.unesa.ac.id /index.php/mathedunesa/article/do wnload/16685/15155, diakses tanggal 1 November 2019)

Karso, dkk. (2008). Pendidikan Matematika 1. Jakarta: Universitas Terbuka.

Muhsetyo, Gatot, dkk. (2008). Pembelajaran Matematika SD. Jakarta: Universitas Terbuka.

Nayazik, A. dan Sukestiyarno. (2012). Pembelajaran Matematika Model IDEAL Problem Solving dengan Teori Pemrosesan Informasi untuk Pembentukan Pendidikan Karakter dan Pemecahan Masalah Materi Dimensi Tiga Kelas X SMA. Jurnal Pythagoras. Vo. 7 No. 2 (2012). pp. 18. (Online) (https://journal.uny.ac.id/index.php/ pythagoras/article/download/4778/4 137, diakses diakses tanggal 1 November 2019)

Sanjaya, W. (2012). Media Komunikasi Pembelajaran. Jakarta: Kencana.

Sardiman. (2014). Interaksi dan Motivasi Belajar Mengajar. Jakarta: PT Raja Grafindo Persada.

Siswoyo, Dwi., dkk. (2007). Ilmu Pendidikan. Yogyakarta: UNY Press.

Sudjati. (2009). Kumpulan Materi Perkuliahan Penilaian Hasil Belajar Sekolah Dasar (Penilaian Hasil Belajar). Yogyakarta: FIP UNY.
Suherman, E., dkk. (2003). Strategi Pembelajaran Matemaatika Kontemporer. Bandung: Jurusan Pendidikan Matematika. Fakultas Pendidikan MIPA Universitas Pendidikan Indonesia.

Susiana, E. (2010). “IDEAL Problem Solving dalam Pembelajaran Matematika". Kreano Jurnal Matematika KreatifInovatif. Vol. 1 No. 2 (2010). pp. 7382. (Online). https://journal.unnes.ac.id/nju/index .php/kreano/article/1491/1615, diakses tanggal 1 November 2019)

Wena, M. (2011). Strategi Pembelajaran Inovatif Kontemporer Suatu Tinjauan Konseptual Operasional. Jakarta: Bumi Aksara.

Winataputra, U. S., dkk. (2005). Strategi Belajar Mengajar. Jakarta: Universitas Terbuka. 